\title{
The methodology of BSC system in strategic management of non-profit organization in the globalization process
}

\author{
Eva Kicová1, ${ }^{1,}$ Ol'ga Poniščiaková ${ }^{1}$ \\ ${ }^{1}$ University of Zilina, Faculty of Operation and Economics of Transport and Communications, \\ Department of Economics, Univerzitna 1, 01026 Zilina, Slovakia
}

\begin{abstract}
Research background: If globalization presents really a new and not reversible process that creates a more homogenous world, strategies of enterprises should appropriate to this phenomenon, too. European legislation has significantly contributed to the creation of the mutual market and increasing freedom of movement of services within the European Union. This paper examines the issue of using the BSC system methodology in the strategic management of a selected non-profit organization. The aim is to explain the importance and essence of the BSC system methodology in the strategic management of a non-profit organization, to analyse the application and knowledge of the BSC system methodology in practice of selected organizations in Slovakia and apply the essence of the method in strategic management of selected non-profit organizations. The non-profit organizations are an important part of the public sector, which in the form of various activities, in particular the providing of various services, performs tasks related to addressing manifestations of market imbalances. In contrast to the "traditional" business sector (profit sector), the task of the non-profit sector is not to generate profit but to provide consumer tasks.

Purpose of the article: The objective of the article is to clarify and present the specifics of functioning and management of non-profit organizations in the conditions of the Slovak Republic.

Methods: During the elaboration of the paper, the methods of compilation of analysis, synthesis and description were used on the basis of the search of the relevant literature. Part of the paper is a survey, which we conducted through a questionnaire on a selected sample of non-profit organizations in the Slovak Republic.

Findings \& Value added: The results of the survey we have transported into general practice recommendations for non-profit organizations to improve their operating in the conditions of Slovakia while accepting the process of globalization.
\end{abstract}

Keywords: non-profit organizations; strategic management; specifics; process of globalization

* Corresponding author: eva.kicova@ffpedas.uniza.sk 
JEL Classification: $M 30 ;$ M31; M39

\section{Introduction}

Globalization is a process of unification of countries, cultures, economies, and people. Currently, it impacts on every state and thus every industry. It has impact on the functioning of non-profit organizations, too. These organizations have an irreplaceable role in the economy of each state. There are many reasons. Non-profit organizations operate in areas that are unattractive to for-profit organizations because their primary role is not to make a profit, or the state does not offer the opportunity to provide services in these areas on a market basis. Thanks to globalization, the non-profit sector is thus gaining more and more importance in the social focus of the state. That is why it is necessary for non-profit organizations to provide their services as efficiently as possible. One way to achieve this is a well-established and functional strategic management system. Most non-profit organizations in Slovakia have set a mission, vision, but they do not have set specific strategy for achieving goals or do not have knowledge of how to implement the strategy in practice. Given that the use of strategic management in non-profit organizations is to a much lesser extent than in the case of organizations in the for-profit sector. It is important to recruit employees with managerial thinking in non-profit organizations. For this reason the paper focuses mainly on the issue of strategic management with regard to the use of the BSC system concept, taking into account the individual specifics of non-profit organizations.

At present, managers must face a double challenge from all sectors of the social system on a global scale. First, organizations need to mobilize their human capital and information resources. Second, organizations should move towards new strategies in line with the high demands of their informed users and customers (Dengov et al., 2020; Lizbetinova et al., 2021). In general, organizations respond to this challenge by formulating new strategies and concepts to ensure their higher value to customers and partners. The main problem arises with the unsuccessful implantation of new strategy due to difficulties with management and the resulting control over the process. For both profit and non-profit organizations, a look at one indicator cannot provide a clear idea of the state of any system. Organizations need to use a balanced set of measures, which is becoming increasingly important for the effectiveness of strategy implementation (Banabakova et al., 2018).

The Balanced Scorecard (BSC) was created by Analog Devices Inc. (ADI), a mediumsized semiconductor company. From 1986 to 1992, BSC was popularized by Kaplan and Norton. These authors defined it as an integrated management system of the performance of the organization, which serves to transform the strategy into the activities of the organization, a combination of financial and non-financial performance measures. However, so far very few organizations in the corporate world know how to use this strategic performance management tool (Majerova, 2020; Nadanyiova, 2014). It is successfully used only by a small number of organizations (Hamid, 2018). BSC was primary used in profit organizations, later it started to apply in non-profit organizations. In last years, number of studies that tried to analyse BSC in non-profit sector have confirmed that organizations have benefited from this managerial system (Quesado et al., 2017). BSC is a strategic planning and management system widely used in business, government, and non-profit organizations around the world to align business activities with the vision and strategy of the organization, to improve internal and external communication, and to monitor the performance of the organization against strategic goals (Gajanova et al, 2020; Lazarevic et al., 2020). The main role of BSC as a tool for strategic management and control relates to their essence of synthesized expression strategy, which sets sufficiently good preconditions for its implementation. The BSC system helps to identify the key 
success factors and the resulting basic controllable parameters, their target values, and initiatives for their implementation. In principle, this role of the score card serves to manifest control as negative feedback at the strategic level (Terziev et al., 2017). It is important to emphasize the leading role of this system in the control of different areas and at the different levels of organization. E.g. Bulgarian researches, especially that conducted by Dinev, show us that until the establishment of BSC, the element of the control function was considered fragmentary or in many cases absent in the theoretical development of the control function structure (Zahariev et al., 2020).

BSC has a forward-looking orientation, meaning that it addresses the current and future success of the organization, instead of focusing on the most recent reporting period without any indication of performance improvement. BSC integrates external and internal measures, which allows management to examine where previous trade-offs have been made between performance measures and helps ensure that this does not happen in the future (Williams et al., 2020). BSC helps organizations focus on adequate performance areas by attracting the attention of manageres only to the actions that are most relevant to the organization. It does not overburden the organization with much more measures than necessary (Costantini et al., 2020).

The specifics of the development of BSC create sufficient preconditions for their active role as a tool for effective management and control over the strategy development process itself. This role can also be important in the context of implementing strategy concepts. In the process of operationalization of the strategy, it is necessary to prove the causal relationships and the impact of changes on the target results of the organization. Experience shows that in most cases this leads to a reassessment, redefinition, and refinement of the strategy itself (Laktionova et al., 2019).

Dankiewics emphasize that one of the frequently mentioned topics concerning the nonprofit sector in recent years has been the effort to achieve financial stability and sustainability of organizations. Related to this topic is the so-called donor fatigue (the authors understand this concept as the gradual restriction or interruption of donations, or benefits from donors to non-government organizations), which occurs in highly developed countries. It is more frequently reported in the literature that non-government organizations could take more control of their finances and be financially sustainable (Dankiewics et al., 2020).

Financial stability in non-governmental non-profit organizations can be achieved through multi-source funding, which is a combination of funding from public budgets and other sources. Other sources are funds obtained from foundations, corporate and individual donors, and from self-financing. Self-financing means that the organization has income from its own activities. Recently, the number of non-profit organizations dedicated to this method of financing has been growing. The main reason is that an organization can procure resources that it can use at will (Spicka, et al., 2019).

\section{Methodology and data}

Non-profit organizations have an irreplaceable role in the economy. There are many reasons, however, the most important is that non-profit organizations operate in areas that are unattractive to for-profit organizations because their primary role is not to make a profit or the state does not offer market opportunities in these areas (Coatney, Poliak, 2020). Nonprofit organizations operate in such areas that serve the development of the whole society. These areas include education, social services, health care, defense, science, research, culture, and sports (Krechovska et al., 2018). We live in a social society and thus the nonprofit sector is becoming increasingly important, becoming dynamic and constantly evolving (Hyanek, 2011). The non-profit sector not only serves us to promote our own 
values and interests, but also participates in services and activities that are of a nationwide nature. It employs many citizens who have a paid employment or volunteering in this sector. Non-profit organizations can be defined as entities operating in the non-profit sector, which were based on the non-commercial principle, i.e. for the purpose of achieving social benefits of the whole public or a certain group (Hejduková, 2015). The number of nonprofit organizations in the last period in the Slovak Republic is clearly processed in the following table.

Table 1. Number of non-profit organization in Slovakia

\begin{tabular}{|l|r|r|r|r|}
\hline Non-profit organizations & 2017 & 2018 & 2019 & 2020 \\
\hline Budgetary organizations & 6366 & 6353 & 6354 & 6335 \\
\hline Contributary organizations & 663 & 663 & 664 & 664 \\
\hline Other & 22450 & 28676 & 28571 & 31064 \\
\hline Totally & 29479 & 35692 & 35580 & 38063 \\
\hline
\end{tabular}

Source: own collaboration based on www.datacube.statistics.sk

Based on data provided in the table, it is obvious that the number of non-profit organizations operating in Slovakia is growing. In 2020 there were 38,063 non-profit organizations i.e. 8,584 organizations more than in 2017. However, there are still less nonprofit organization than profit-oriented organizations. One of the reasons may be the low average wage of employees in this area, as another reason we can mention the weak financial support of the non-profit sector compared to other European Union countries (Taylor, 2020). Based on surveys conducted by the Pontis Foundation, we can say that in 2019, drawing on the European Union grant schemes administered by the Slovak government continued to be problematic. Complaints of non-profit organizations are dominated by excessive bureaucratic burden and unprofessional approach on the part of civil servants, non-compliance with deadlines, and insufficient communication. This situation led to a general decline in the use of the European Union funds (Mazanec, Bartosova, 2019). At the end of 2019, for example, only $26 \%$ of funds were used (Shemyatikhina et al, 2020).

Specifics influencing strategic management in non-profit organizations non-profit organizations can be distinguished from profit-oriented organizations on the basis of various characteristics, which also affect the process of strategic management in non-profit organizations (Majduchova, 2009):

- Services that are provided by non-profit organizations are difficult to measure and to touch.

- Customers have a weak impact on provided products and services.

- In non-profit organizations there are employed mostly employees, who feel responsible and companionship to the goals of the organization.

- Internal management is greatly affected by the receipt of resources from various contributors and donors.

- The structure of non-profit organizations causes problems in obtaining money on the capital market. Therefore, non-profit organizations make use of indirect funding opportunities, which they must combine appropriately. It is necessary to ensure the creation of a broad financial portfolio in order to avoid that the organization is dependent on one financial source.

- Non-profit organizations, although their main activity is not focused on the commercial market, should use marketing. They have to adapt their management according to the orientation towards customers who have different requirements. For non-profit organizations, marketing mainly involves communication with customers, working with the media and building public relations. 
- In the case of changes in the organization and conflict resolution, it is important to take decisions into account the current situation in the organization.

- The non-profit sector includes a set of organizations that can take different forms and perform different activities. The number of non-profit organizations is constantly increasing and they are starting to increase their competitiveness. Many of them still use funds as indicators to measure their performance. There is now an increasing need to include non-financial indicators to assess their performance and level of strategic management (Anheier, 2019).

\section{Results}

This part of the paper is a survey, which we conducted through a questionnaire on a selected sample of non-profit organizations in the Slovak Republic.

The traditional methods of measuring performance of processes have basic shortcomings in it that they are only able to provide a retrospective view of the competitive position of the analyzed organization, whose activities have only been recorded in a certain period in the past. Analyses of this type are incomplete and outdated. They are able to provide only a small number of usable options for revealing the true variability and dynamics of factors that speak about the profitability of an organization. As a result, the traditional methods of measuring process efficiency need to be complemented by a set of non-financial, more dynamic indicators that are tailored to the specific competitive conditions of the organization.

During January to February 2020, we carried out a survey in the form of a questionnaire survey aimed at identifying and comparing the strategic orientation of the non-profit sector in comparison with the profit sector. The selection of respondents was made through a database from Finstat and we searched for contact details using the Azet catalog. We addressed the respondents through email communication and a social network. We contacted 100 respondents, of which 50 respondents represented organizations from the non-profit sector, which we named in our survey as "non-profit organizations". Another 50 respondents represented other organizations that fall under the for-profit sector, and in our survey we referred to them as "for-profit organizations." We addressed respondents from all over Slovakia. However, the return was only $48 \%$, which was caused by the critical situation in connection with the COVID-19 pandemic. Based on the survey, we can state that there are some differences in setting goals for the future for profit and non-profit organizations. In the case of non-profit organizations, as we can see in the picture, we show that they focus most on the goals that concern customers, such as their satisfaction and increasing market share. In the case of for-profit organizations, we can say that their goals are focused mainly on finances, i.e. increasing profits, increasing sales, reducing costs. Increasing market share is also one of their goals.

It was also interesting to note that less than $50 \%$ of non-profit organizations do not use a predetermined strategy to achieve their goals, and about $20 \%$ of the addressed organizations do not know what the strategy is.

We also investigated the use from our point of view of standard management methods in organizations in Slovakia. For comparison with abroad, we used the Bain \& Company survey from 2017 "Management Tools \& Trends". 1,268 managers from around the world participated in this survey. These surveys were conducted 25 times in 1993 to 2017. The latest survey shows that the BSC method is used by $29 \%$ of respondents. The BSC is one of the most used management methods abroad. This is evidenced by surveys by Bain \& Company.

Based on these findings of Bain \& Company, we want to determine the use of the BSC in Slovakia and compare these results with a foreign survey. This survey focuses not only 
on the comparison of the usability of management methods at home and abroad, but also on the comparison of profit and non-profit organizations in Slovakia. We selected 11 management methods, of which the first 10 are, according to Bain \& Company, the most used in 2017. We supplemented these 10 methods with a Balanced Scorecard, which was placed in 13th position and thus had a slight decrease compared to the 2014 survey. However, we consider this method to be crucial. Respondents could also mention the 12th method as other. Only one respondent identified this term and stated that in their non-profit organization it is used as a method of Pastoral planning:

Table 2. Managerial methods

\begin{tabular}{|l|c|c|c|c|c|c|}
\hline \multirow{2}{*}{ Method } & \multicolumn{2}{|c|}{ Totally } & \multicolumn{2}{c|}{$\begin{array}{c}\text { Non-profit } \\
\text { organization }\end{array}$} & \multicolumn{2}{c|}{$\begin{array}{c}\text { Profit } \\
\text { organization }\end{array}$} \\
\cline { 2 - 7 } & Počet & $\%$ & Počet & $\%$ & Počet & $\%$ \\
\hline Customer satisfaction & 43 & 90 & 23 & 100 & 20 & 80 \\
\hline Customer Relationship Management (CRM) & 42 & 88 & 19 & 83 & 23 & 92 \\
\hline Strategic planning & 38 & 79 & 13 & 57 & 25 & 100 \\
\hline Formulation of vision and mission & 33 & 69 & 16 & 70 & 17 & 68 \\
\hline Total Quality Management (TQM) & 27 & 56 & 10 & 43 & 17 & 68 \\
\hline Benchmarking & 26 & 54 & 4 & 17 & 22 & 88 \\
\hline Advanced Analytiscs & 12 & 25 & 1 & 4 & 11 & 44 \\
\hline Supply chain management & 10 & 21 & 1 & 4 & 9 & 36 \\
\hline Digital transformation & 10 & 21 & 2 & 9 & 8 & 32 \\
\hline Change management & 7 & 15 & 1 & 4 & 6 & 24 \\
\hline Balanced Scorecard (BSC) & 2 & 4 & 0 & 0 & 2 & 8 \\
\hline Pastoral planning & 1 & 2 & 1 & 4 & 0 & 0 \\
\hline
\end{tabular}

Source: own collaboration

\section{Discussion}

Based on the findings from the research, it can be stated that using of the BSC system in the world is more obvious than in Slovakia. In case of organizations in Slovakia that use this system, we have found out that none of the organizations use the BSC system in practise. From this point of view we consider the implementation of the BSC system to be a key issue to gaining a strategic advantage in the non-profit sector as well. The introduction of the BSC system methodology into a non-profit organization can be described in the following steps:

1. Defining of strategic goals of non-profit organization. Before defining strategic goals, it is generally necessary to classify them into certain groups; in the case of the BSC system, we are talking about four perspectives. In order to achieve the effective creation of the BSC system, the objectives must generally be linked to the following perspectives: customer perspective; internal processes perspective; learning and growth perspective; financial perspective. The ranking of given perspectives must be adapted to their importance and at the same time to the specifics of non-profit organizations. Profit in the case of non-profit organizations is not the primary goal, so we adjusted the structure of the BSC system to the requirements and specifics of non-profit organizations as follows: 


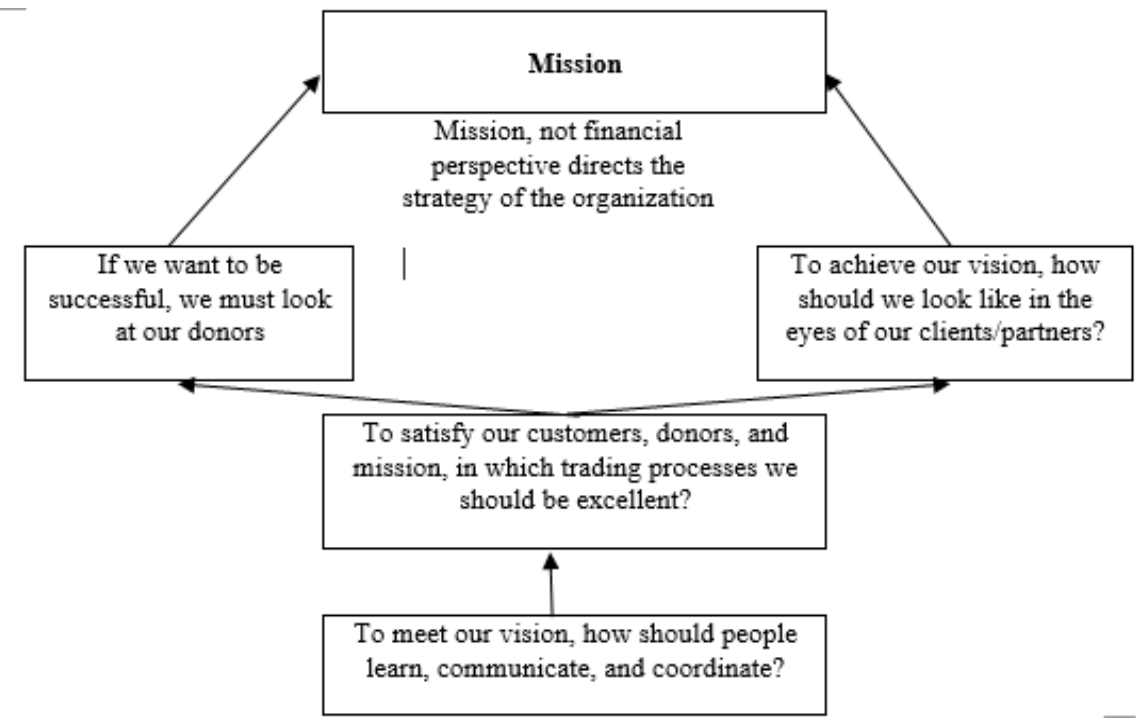

Figure 1. Suggested perspectives of BSC system in non-profit organization

Source: own collaboration

2. Assignment of competencies and responsibilities for defined goals. It is essential that responsible employees are assigned to the individual goals within the defined perspectives, who have the necessary competencies in the management of the nonprofit organization adapted to it.

3. Linking strategic goals by creating cause-and-effect relationships in the form of a strategic map. At the top of the strategic map, we recommend placing the mission and below it the elaboration of individual strategic goals for individual perspectives in order: customer perspective, perspective of internal processes, perspective of learning and growth and financial perspective. It depends on the management of which nonprofit organization, whether the chosen order will follow, resp. to what extent it will follow individual perspectives.

4. Selection of indicators of specific strategic objectives and their recommended values. To achieve strategic goals, it is not enough to define them, it is necessary to determine indicators for individual perspectives, based on which we can quantify the goals. The individual indicators of strategic goals can be divided into financial and non-financial, but due to the specifics of a non-profit organization, we will be dominated by non-financial indicators, which are more difficult to quantify.

5. Identification of strategic actions. To achieve the individual strategic goals, it is not enough to set indicators and target values, it is necessary to determine the strategic actions through which the non-profit organization will gradually meet the individual strategic goals in the selected perspectives.

6. Control of achieved results in the individual perspectives. It is necessary to realize that the control of the achieved results can contribute to the achievement of the defined mission and vision of the company, reveal shortcomings and allow to create new materials for the needs of strategic management of a non-profit organization.

\section{Conclusion}

In recent decades marked by globalization, there has been a rapid development of concepts and systems for the management of organizations. Special attention is focused on strategic 
management. The paper focuses on the Balanced Scorecard system and its use in strategic management in non-profit organizations in the Slovak Republic.

The part of the paper is also a survey, on the basis of which we came to the conclusion that non-profit organizations focus primarily on the goals that are characteristic of the customer perspective. For-profit organizations focus on the objectives of the financial perspective. Subsequently, we found that compared to for-profit organizations, non-profit organizations have a lesser set strategy. We also found that the BSC is not used by any of the surveyed non-profit organizations. We implemented the content of the last part of the goal in the chapter suggestions and recommendations. We applied the essence of the BSC in the strategic management of a selected non-profit organization. In the strategic action step, we set a number of proposals to achieve strategic goals. If a non-profit organization decides to implement the BSC, it will result in many benefits. The design of the BSC system can serve as a guide for the creation and application of this system for other nonprofit organizations.

\section{Acknowledgements}

Grant No. 1/0544/19 Formation of the methodological platform to measure and assess the effectiveness and financial status of non-profit organizations in the Slovak Republic.

\section{References}

1. Coatney, K., \& Poliak, M. (2020). Cognitive Decision-Making Algorithms, Internet of Things Smart Devices, and Sustainable Organizational Performance in Industry 4.0based Manufacturing Systems. Journal of Self-Governance and Management Economics, 8(4), 9-18.

2. Costantini, A., Landi, S., \& Bonazzi, M. (2020, January 2). Factors Influencing the Use of the Balanced Scorecard: Evidence from a Regional Context. Department of Management, Università Ca' Foscari Venezia Working Paper No. 7. https://ssrn.com/abstract=3511794

3. Dankiewicz, R., Ostrowska-Dankiewicz, A., \& Bulut, C. (2020). The attitudes of entrepreneurs of the small and medium-sized enterprises sector in Poland to key business risks. Equilibrium. Quarterly Journal of Economics and Economic Policy, 15(3), 511-536.

4. Dengov, V., Tulyakova, I., Gregova, E., \& Sviridov, G. (2020). Price strategies of mobile operators in Russia in the conditions of the global economic recession. Oeconomia Copernicana, 11(2), 347-370.

5. Gajanova, L., Nadanyiova, M., Musat, M., Bogdan, A. (2020). The social recruitment as a new opportunity in the Czech Republic and Slovakia. Ekonomicko-manazerske spektrum, 14(1), 65-76.

6. Hejdukova P. (2015). Veřejné finance. Praha: C. H. Beck.

7. Hyanek V. (2011). Neziskové organizace: teorie a mýty. Brno: muni PRESS.

8. Krechovska M. (2018). Řizení neziskových organizací. Praha: Grada Publishing.

9. Laktionova, O., Dobrovolskyi, O., Karpova, T., \& Zahariev, A. (2019). Cost efficiency of applying trade finance for agricultural supply chains. Management Theory and Studies for Rural Business and Infrastructure Development.41(1), 62-73. 
10. Lazarevic, D., Dobrodolac, M., Svadlenka, L., \& Stanivukovic, B. (2020). A model for business performance improvement: a case of the postal company. Journal of Business Economics and Management, 21(2), 564-592.

11. Lizbetinova, L., Hitka, M., Sousek, R., \& Caha, Z. (2021) Motivational preferences within job positions are different: empirical study from the Czech transport and logistics enterprises. Economic Research-Ekonomska Istraživanja, 34(1), 2387-2407.

12. Majduchova, H. (2009). Neziskové organizácie. Bratislava: Sprint dva.

13. Majerova, J. (2020). Monistic concept of branding has broken: How to guarantee consistency in brand value management? Polish Journal of Management Studies, 22(2), 232-246.

14. Mazanec, J., \& Bartosova, V. (2019). Financial vulnerability of non-profit organizations in the Slovak Republic. Proceedings of the 33rd International Business Information Management Association Conference, Education Excellence and Innovation Management through Vision 2020, 1051-1066.

15. Nadanyiova, M. (2014). Japanese management and its practice in company branch based in Slovakia. In J. Stankeviciene, R. Ginevicius, \& A. V. Rutkauskas (Eds.), Proceedings of the 8th International Scientific Conference on Business and Management (546-554).

16. Nadanyiova, M., \& Durana, P. (2019). Corporate social responsibility as a brand valueenhancing tool. In M. L. Simic \& B. Crnkovic (Eds.), Proceedings of the 8th International Scientific Symposium Economy of Eastern Croatia-Vision and Growth (1225-1237).

17. Quesado P. R., Rodrigues, L. L., \& Guzman, B. A. (2017). The perceived uncertainty of the environment and the support of top management in the implementation of the Balanced Scorecard. Revista Contabilidade e Controladoria - RC C, 9(2), 11-22.

18. Rebetak, F., \& Bartosova, V. (2020). Non-profit organizations in the conditions of Slovakia. SHS Web of Conferences, 74, 05020.

19. Shemyatikhina, L., Shipitsyna, K., \& Usheva, M. (2020). Marketing management of a non-profit organization. Ekonomicko-manazerske spektrum, 14(1), 19-29.

20. Sreelakshmi G. (2017). Implementation and Practicalities of Balance Scorecard: A Case Study. Asian Journal of Applied Science and Technology, 1(1), 61-67.

21. Spicka J. et al. (2019). Selected socioeconomic determinants of the size of the nonprofit sector serving households in the OECD countries. Prague Economic Papers, 28(3), 276- 295.

22. Taylor, P. (2020). Big Data Management and Urban Sustainability Analytics of Smart Governance. Geopolitics, History, and International Relations, 12(1), 66-72.

23. Terziev V. et al. (2020). Balanced Scorecard - Analysis of Theoretical and Applied Solution. Proceedings of the 62nd International Scientific Conference on Economic and Social Development. Lisbon: Economic and Social Development, 367-376.

24. Williams, A., Suler, P., \& Vrbka, J. (2020). Business Process Optimization, Cognitive Decision-Making Algorithms, and Artificial Intelligence Data-driven Internet of Things Systems in Sustainable Smart Manufacturing, Journal of Self-Governance and Management Economics, 8(4), 39-48.

25. Zahariev A. et al. (2020). Debt management evaluation through support vector machines: on the example of Italy and Greece. Entrepreneurship and Sustainability center, 7(3), 2382-2393. 